\title{
Influence of Temperature on the Antibacterial Activity of Sodium Hypochlorite
}

Luciano Giardino ${ }^{1}$, Zahed Mohammadi2 ${ }^{2}$, Riccardo Beltrami ${ }^{3}$, Claudio Poggio ${ }^{4}$, Carlos Estrela ${ }^{5}$, Luigi Generali ${ }^{6}$

\begin{abstract}
The aim of this study was to compare the antimicrobial activity of $5.25 \% \mathrm{NaOCl}$, Hypoclean and Chlor-Xtra at $20^{\circ} \mathrm{C}$ and $45^{\circ} \mathrm{C}$ in bovine root dentin. One-hundred-and-seventy dentin tubes prepared from bovine maxillary incisors were infected for 21 days with Enterococcus faecalis. The specimens were divided into the following groups: $1.5 .25 \% \mathrm{NaOCl} 20{ }^{\circ} \mathrm{C}$; 2. Hypoclean $20{ }^{\circ} \mathrm{C}$; 3. Chlor-Xtra $20{ }^{\circ} \mathrm{C} ; 4.5 .25 \% \% \mathrm{NaOCl} 45^{\circ} \mathrm{C} ; 5$. Hypoclean $45^{\circ} \mathrm{C} ; 6$. Chlor-Xtra $45^{\circ} \mathrm{C} ; 7$. positive control; 8 . negative control. Dentin chips were collected with round burs into Brain Heart Infusion (BHI) broth. After culturing, the number of colonyforming units (CFU) was counted. Statistical analyses were performed using descriptive statistics (mean, standard deviation, median), Shapiro-Wilk test, ANOVA and Tukey test. Significance level was set at $p<0.05$. In all experimental groups, CFU was minimum after treatment (day 0 ) and the obtained results were significantly different from each other at any period $(p<0.05)$. After treatment, the Hypoclean and Chlor-Xtra showed the lowest numbers of CFU at $20{ }^{\circ} \mathrm{C}$ and $45^{\circ} \mathrm{C}$, whereas $5.25 \% \mathrm{NaOCl}$ showed the highest number of CFU at both temperatures. In each group, the number of CFUs increased significantly with time $(p<0.05)$. The antibacterial activity of Hypoclean and Chlor-Xtra at $45^{\circ} \mathrm{C}$ were significantly greater than other tested solutions.
\end{abstract}

Key Words: irrigants, temperature, sodium hypochlorite, surfactants, antimicrobial action, Enterococcus faecalis.

\section{Introduction}

Microorganisms persisting after sanitization process contribute significantly to failure of root canal treatment (1). The eradication of microorganisms from root canal systems is complex and requires a combined use of instrumentation and infection control strategies (2). The mechanical instrumentation is not able to eliminate completely the bacteria from the root canal system (3). Ex vivo studies and clinical evidence have shown that mechanical instrumentation leaves untouched significant areas of the root canal walls $(1,2,4,5)$. Therefore, some irrigation strategies are necessary to remove residual tissue and to control microorganisms (5).

An alternative protocol is to use antimicrobial agents that exhibit a higher antibacterial effectiveness to overcome the above-mentioned problems. Sodium hypochlorite $(\mathrm{NaOCl})$ is the most commonly used root canal irrigation solution. It has both tissue-dissolving and antimicrobial properties (6). One of the major drawbacks of $\mathrm{NaOCl}$ is its high surface tension, which limits its penetration into irregularities of the root canal system such as fins, isthmi and dentinal tubules (7). $\mathrm{NaOCl}$ does not exert any residual antimicrobial activity (8) so that the recolonization of persistent microorganisms cannot
'Scientist Researcher, Private

Practice, Crotone, Italy

${ }^{2}$ Iranian Center for Endodontic

Research (ICER), Research Institute

of Dental Sciences Shahid

Beheshti, University of Medical

Sciences, Iranian National Elite

Foundation, Tehran, Iran

${ }^{3}$ Department of Brain, Behavioral

Sciences, Section of Statistics,

University of Pavia, Italy

${ }^{4}$ Department of Clinical, Surgical,

Diagnostic and Pediatric

Sciences, Section of Dentistry,

University of Pavia, Pavia, Italy

${ }^{5}$ Department of Stomatological

Sciences, Dental School, UFG

- Universidade Federal de

Goiás, Goiânia, G0, Brazil

${ }^{6}$ Department of Surgery, Medicine,

Dentistry and Morphological Sciences with Transplant Surgery, Oncology and Regenerative Medicine Relevance, School of Dentistry, Endodontic Section, University of Modena and Reggio Emilia, Modena, Italy

Correspondence: Prof. Luciano Giardino, Via Marinella 12, 88900 Crotone, 1taly. Tel: 039 0962905137, Crotone, Italy. e-mail: lucianogiardino@libero.it be prevented. Thus, infected or contaminated dentin may turn a potential source of persistent apical periodontitis. A possible way of improving the bactericidal efficacy of the disinfecting solutions has been to incorporate different detergents as surface-active agents, enhancing their wetting properties $(9,10)$. High wettability is supposed to enable deeper penetration into the dentinal tubules of the antibacterial solutions. Hypoclean (Ogna Laboratori Farmaceutici, Muggiò, Italy), a new commercially available $\mathrm{NaOCl}$-based irrigant modified with surfactants, showed surface tension values $\left(29.13 \mathrm{~mJ} / \mathrm{m}^{2}\right)$ significantly lower than the regular $5.25 \% \mathrm{NaOCl}\left(48.90 \mathrm{~mJ} / \mathrm{m}^{2}\right)$ (7). A recent analysis showed the superior wettability of Hypoclean and Chlor-Xtra $(<6 \% \mathrm{NaOCl}$ solution modified with Triton X100, proprietary surface modifiers and alkylating agents; Vista Dental, Racine, WI, USA) over dentin in comparison to $5.25 \% \mathrm{NaOCl}$. In fact they spread immediately on dentin surface, yielding a zero-degree contact angle (10). Hypoclean demonstrated a more effective antibacterial action against Enterococcus faecalis than $5.25 \% \mathrm{NaOCl}$ at all experimental periods $(7,14,21,28$ days $)$ in bovine root dentin and displayed no bacterial growth at days 7 and 14 after treatment (11). Low surface tension may improve the antimicrobial efficacy of $\mathrm{NaOCl}$ by increasing 
its penetration ability into inaccessible areas of the root canal system (RCS) and dentinal tubules.

Heating the sodium hypochlorite solutions can also change the tissue-dissolving capacity and bactericidal action (12-14). Abou-Rass and Oglesby (12) verified that regardless of concentration ( $2.6 \%$ or $5.25 \%)$, the sodium hypochlorite solutions heated to $140{ }^{\circ} \mathrm{F}\left(60^{\circ} \mathrm{C}\right)$ were superior in dissolving rat connective tissue. Cunningham and Joseph (14) also compared the ability of the solutions to kill bacteria at different temperatures $\left(21{ }^{\circ} \mathrm{C}\right.$ and 37 ${ }^{\circ} \mathrm{C}$ ), and tested the ability of $2.6 \%$ sodium hypochlorite in reducing a planktonic culture of Staphylococcus aureus, Streptococcus sanguis, Escherichia coli, Proteus vulgaris and Bacillus subtilis spores. Time to kill in vitro bacterial cultures was found to be significantly reduced at $37{ }^{\circ} \mathrm{C}$. Results about an increased antibacterial capacity of heated $\mathrm{NaOCl}$ solutions were later confirmed by Sirtes et al. (15) who assessed the antimicrobial activity of the preheated solution. This study demonstrated a 100 -fold increase in killing efficacy on $E$. faecalis between $\mathrm{NaOCl}$ solutions at $20{ }^{\circ} \mathrm{C}$ and $45{ }^{\circ} \mathrm{C}$. Temperature increases not only the bactericidal action and tissue-dissolving capabilities of sodium hypochlorite solutions, but it is also one of the primary influencing variables affecting fluid viscosity and surface tension of $\mathrm{NaOCl}$-based irrigants (15-17). When a liquid is heated the kinetic energy increases, its molecules become excited and begin to move. The energy of this movement is enough to overcome the forces that bind the molecules together, allowing the liquid to become more fluid and decreasing its viscosity. This phenomenon may be explained by thermal agitation of the molecules that move faster at $37{ }^{\circ} \mathrm{C}$ than at $22^{\circ} \mathrm{C}(16)$. With the rise in temperature the surface tension also decreases because the kinetic energy (speed) of the molecules increases. Thus, the strength of intermolecular forces decreases, resulting also in the decline of surface tension (18).

The aim of this study was to evaluate the effectiveness of some $\mathrm{NaOCl}$ irrigants at different temperatures $\left(20^{\circ} \mathrm{C}\right.$ or $\left.45^{\circ} \mathrm{C}\right)$ and time intervals $(0,7,14,21$ and 28 days) on E. faecalis infected bovine root dentin.

\section{Material and Methods}

The method of this study was based on the procedure previously described by Haapasalo and Ørstavik (19). Extracted bovine permanent maxillary anterior teeth were used. All teeth were kept in $0.5 \% \mathrm{NaOCl}$ solution for up to 7 days. The coronal and apical thirds were removed from each tooth with a rotary diamond saw at $1000 \mathrm{rpm}$ (Isomet Plus precision saw; Buehler, IL, USA) under water-cooling. Cementum was eliminated by using polishing paper (Ecomet 3, variable-speed grinder-polisher; Buehler), which resulted in a center-holed piece of root dentin with a 6-mm outer diameter. The remaining piece of each tooth was then cut into 4-mm thick slices with a diamond saw, as above. The root canals of the 4-mm blocks were enlarged (standardized) with an ISO 023 slow speed round bur. All teeth and dentin slices were preserved in phials containing tap water during the procedures to prevent dehydration.

Each dentin block $(n=170)$ was individually treated with $5.25 \% \mathrm{NaOCl}$ and $17 \%$ ethylene diamine tetraacetic acid (EDTA) (pH 7.2), placed in an ultrasonic bath for $10 \mathrm{~min}$ and washed in tap water for $1 \mathrm{~h}$ to remove the smear layer. The specimens were then placed in brain heart infusion (BHI) broth (Oxoid, Basingstoke, UK) and autoclaved. To monitor the efficacy of the sterilization they were maintained in an incubator at $37{ }^{\circ} \mathrm{C}$ for $24 \mathrm{~h}$. One bottle of Chlor-Xtra (Vista Dental Products; Racine, WI, USA) was purchased shortly before the beginning of the project; the solution was immediately transferred to an amber glass bottle, kept at 4 ${ }^{\circ} \mathrm{C}$ (following the recommendations of the manufacturer) and brought to room temperature before use. $5.25 \% \mathrm{NaOCl}$ solutions were prepared by diluting a stock solution of $15 \% \mathrm{NaOCl}$ (Ogna) in distilled water. Hypoclean solution (Ogna) was also freshly prepared by mixing $5.25 \% \mathrm{NaOCl}$ and surfactants. The experiments were done at $20^{\circ} \mathrm{C}$ and $45^{\circ} \mathrm{C}$. A water bath (BM 4 Falc Instruments, Treviglio, $\mathrm{BG}$, Italy) was used for the experiments at $20^{\circ} \mathrm{C}$ and 45 ${ }^{\circ} \mathrm{C}$. The temperature of the solutions was checked with a thermometer (Checktemp Hanna Nord EST SRL Baranzate, MI, Italy).

One-hundred-and seventy specimens were randomly divided into groups as follows: 1. $5.25 \% \mathrm{NaOCl}$ (Ogna) $(\mathrm{n}=25)$ at $20^{\circ} \mathrm{C} ; 2$. Hypoclean $(5.25 \% \mathrm{NaOCl}$ modified with cetrimide and polypropylene glycol) (Ogna) $(n=25)$ at 20 ${ }^{\circ} \mathrm{C}$; 3. Chlor-Xtra (<6\% NaOCl modified with Triton X100, proprietary surface modifiers and alkylating agents) (Vista) $(n=25)$ at $20{ }^{\circ} \mathrm{C} ; 4.5 .25 \% \% \mathrm{NaOCl}(\mathrm{Ogna})(\mathrm{n}=25)$ at $45^{\circ} \mathrm{C}$; 5. Hypoclean (Ogna) $(n=25)$ at $45^{\circ} \mathrm{C} ; 6$. Chlor-Xtra (Vista) $(\mathrm{n}=25)$ at $45^{\circ} \mathrm{C} ; 7$. Negative control (sterile dentin tubes) $(n=10) ; 8$. Positive control (infected dentin tubes) $(n=10)$.

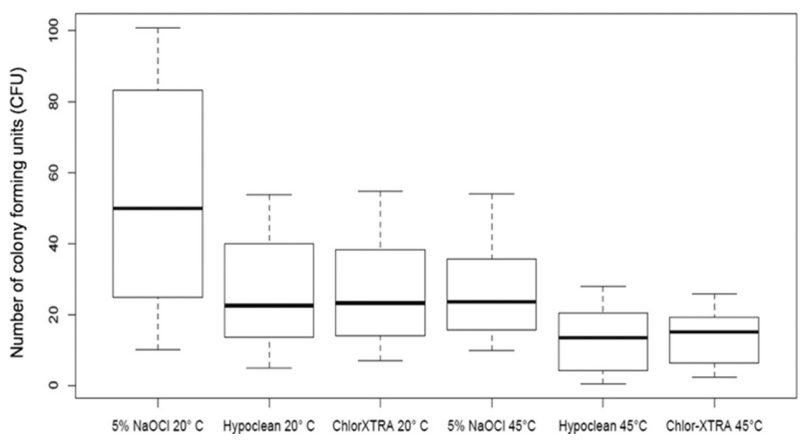

Figure 1. Box-plot of antibacterial effects for each irrigating solution at different temperatures. 
Isolated 24-h colonies of pure cultures of $E$. faecalis (ATCC 29212) were suspended in $5 \mathrm{~mL}$ of BHI. The bottles containing each specimen in Groups 1, 2, 3, 4, 5 and 6 were opened in a laminar flow chamber. Two milliliters of sterile $\mathrm{BHI}$ were removed with sterile pipettes and replaced with $2 \mathrm{~mL}$ of bacterial inoculum. The bottles were closed and kept at $37^{\circ} \mathrm{C}$ for 28 days, with the replacement of $1 \mathrm{~mL}$ of contaminated BHI for $1 \mathrm{~mL}$ of freshly prepared BHI every 2 days, to avoid medium saturation. After the contamination period, the bacterial growth was verified by a histological technique (Brown and Brenn staining method). Then, each specimen was removed from its bottle in aseptic conditions, and the root canal was irrigated with $5 \mathrm{~mL}$ of sterile saline and dried with sterile paper points. The outer surface of the specimens was covered with two layers of nail polish to prevent contact of the medicament with the external surface. After that, using decontaminated sticky wax, specimens were fixed at the bottom of 24-well cell culture plates, which also obliterated the apical surface of the root canal. Finally, the irrigating solutions were delivered into the canal lumen with sterile $3-\mathrm{mL}$ plastic syringes and 27-gauge needles until the dentin tubes were totally filled. Solutions were removed using sterile paper points $10 \mathrm{~min}$ $\dot{s}$ after placement into the lumen. The specimens were then incubated at $37{ }^{\circ} \mathrm{C}$ for 28 days to maintain humidity. At experimental times of $0,7,14,21$ and 28 days, dentin chips were removed from the root canals by sequential sterile low-speed round burs with increasing diameters of ISO sizes: 025, 027, 029, 031 and 033, respectively. Each bur removed approximately $0.1 \mathrm{~mm}$ of dentin around the canal. The powder dentin samples obtained with each bur were immediately collected in separate test tubes containing 3 $\mathrm{mL}$ of freshly prepared BHI. After that, $100 \mu \mathrm{L}$ from each test tube was cultured on blood agar. Grown colonies were counted and recorded as colony-forming units (CFU).

Table 1. Descriptive statistics of the data obtained for each irrigating solution

\begin{tabular}{lccc}
\hline Solution & $\mathrm{n}$ & Mean (SD) & Range \\
\hline 5\% NaOCl $20^{\circ} \mathrm{C}$ & 125 & $43.25(34.59) \mathrm{A}$ & $0-100.86$ \\
Hypoclean $20^{\circ} \mathrm{C}$ & 125 & $21.30(17.56) \mathrm{B}$ & $0-53.71$ \\
Chlor-XTRA $20{ }^{\circ} \mathrm{C}$ & 125 & $21.44(16.66) \mathrm{B}$ & $0-54.77$ \\
$5 \% \mathrm{NaOCl} 45{ }^{\circ} \mathrm{C}$ & 125 & $21.45(16.01) \mathrm{B}$ & $0-54.1$ \\
Hypoclean $45{ }^{\circ} \mathrm{C}$ & 125 & $10.72(9.76) \mathrm{C}$ & $0-28.02$ \\
Chlor-XTRA $45{ }^{\circ} \mathrm{C}$ & 125 & $11.02(8.40) \mathrm{C}$ & $0-25.77$ \\
\hline
\end{tabular}

n: number of specimens; SD: standard deviation; range: MinimumMaximum. Different capital letters indicate statistically significant differences between irrigating solutions. Significance for $\mathrm{p}<0.05$.

\section{Statistical Analysis}

Statistical analysis was performed with Stata 12.0 software (Stata, College Station, TX, USA). Descriptive statistics, including mean, standard deviation, median, and minimum and maximum values were calculated for all irrigating solutions.

The normality of data was checked using the ShapiroWilk test. Analysis of variance (ANOVA) was applied to determine if there were significant differences in antibacterial effects among the irrigating solutions. Tukey's post-hoc test was used. Mean comparison test for paired data was applied to assess significant differences for each antibacterial irrigating solution after 28 days. Significance for all statistical tests was set at $p<0.05$.

\section{Results}

Table 1 reports the CFU average values recorded at each time point for each irrigant employed. ANOVA showed the presence of significant differences among irrigating solutions $(p<0.0001)$ (Table 1 and Figures 1 and 2). The post-hoc Tukey test showed that $5 \% \mathrm{NaOCl} 20^{\circ} \mathrm{C}$ obtained the highest number of colony forming units (CFU) among all irrigating solutions, thus meaning low antimicrobial efficacy. Tukey test did not show any significant difference between the numbers of CFU of Hypoclean $20{ }^{\circ} \mathrm{C}$, ChlorXTRA $20{ }^{\circ} \mathrm{C}$ and $5 \% \mathrm{NaOCl} 45^{\circ} \mathrm{C}(\mathrm{p}>0.05)$. Significantly lower numbers of $\mathrm{CFU}$ were obtained with Hypoclean $45^{\circ} \mathrm{C}$ and Chlor-XTRA $45^{\circ} \mathrm{C}(\mathrm{p}<0.0001)$. All irrigating solutions showed a significant increase in CFU numbers over time as shown in Figure $2(p<0.0001)$.

\section{Discussion}

There are several ways to increase the antibacterial activity of root canal irrigants. One of these ways is heating. The results of current study showed that both Chlor-XTRA
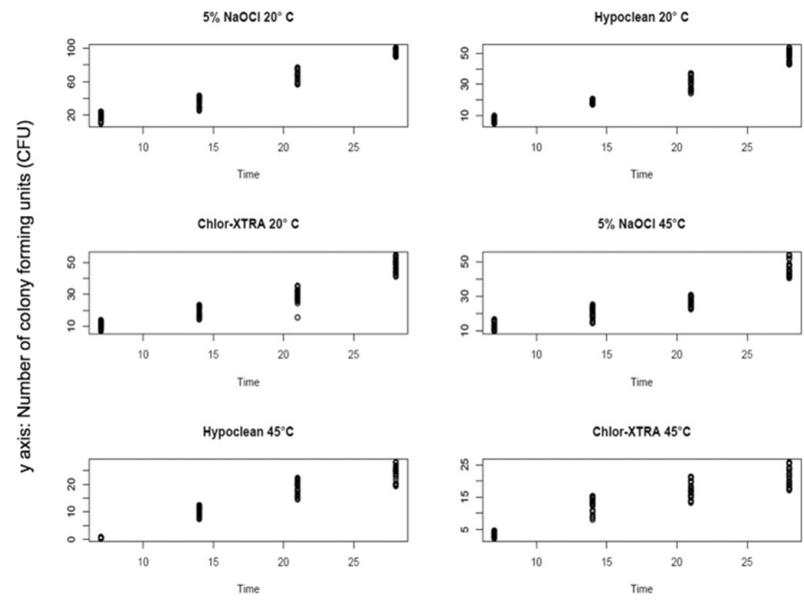

Figure 2. Variation in time of antibacterial effects for each irrigating solution. 
and Hypoclean at $45{ }^{\circ} \mathrm{C}$ presented the lowest CFU counts, which suggests that heating increased the effectiveness of $\mathrm{NaOCl}$-based irrigants. This action may be attributed to the effect of both surfactants and temperature rise.

Studies have shown the influence of temperature of sodium hypochlorite on the antibacterial activity $(13,14)$. Mohammadi et al. (20) verified that $\mathrm{NaOCl}-$ based irrigants possess the most effective antimicrobial activity on E. faecalis, Candida albicans, Actinomyces israelii, Lactobacillus casei and Pseudomonas aeroginosa. Hypoclean was the most effective agent against $L$. casei, P. aeroginosa and $C$. albicans, while Chlor-XTRA was the most efficient irrigant against $A$. israelii. Due to its high surface tension (21), regular $\mathrm{NaOCl}$ cannot penetrate into deeper layers of dentin. Palazzi et al. (7) showed that the surface tension of $\mathrm{NaOCl}$ solutions with added detergents (Hypoclean and Chlor-XTRA) were lower than $\mathrm{NaOCl}$, agreeing with the findings of the present study. An ex vivo study compared the antibacterial power of $1 \% \mathrm{NaOCl}$ with $1 \%$ acetic acid, $5.25 \% \mathrm{NaOCl}$ and two $\mathrm{NaOCl}$ modified with surfactants in bovine root dentin at different days (22). According to the findings, all the $\mathrm{NaOCl}$ solutions showed small number of CFU over 28 days. $\mathrm{NaOCl}$ solutions with added surfactants had the smallest number of CFU at all times with greater antimicrobial efficacy than $5.25 \% \mathrm{NaOCl}$ and $1 \% \mathrm{NaOCl}$ solution with $1 \%$ acetic acid. Bolfoni et al. (23) evaluated the antimicrobial activity of sodium hypochlorite $(5 \%, 2.5 \%$ and $1 \%$ ) associated with a surfactant in human teeth infected with Enterococcus faecalis. The addition of surfactant increased the antimicrobial activity of $1 \% \mathrm{NaOCl}$ to levels similar to $5 \% \mathrm{NaOCl}$. Sirtes et al. (14) verified that the $1 \% \mathrm{NaOCl}$ solution at $45^{\circ} \mathrm{C}$ dissolved pulp tissues as effectively as the $5.25 \%$ solution at $20^{\circ} \mathrm{C}$, while the $60^{\circ} \mathrm{C} / 1 \%$ solution was significantly more effective, exhibiting a 100 -fold increase in killing efficacy on $E$. faecalis between corresponding $\mathrm{NaOCl}$ solutions at $20^{\circ} \mathrm{C}$ and $45^{\circ} \mathrm{C}$.

The data of this study confirm the best antibacterial activity of the $\mathrm{NaOCl}$ solutions heated at $45^{\circ} \mathrm{C}$ compared to non-heated solutions $\left(20^{\circ} \mathrm{C}\right)(13,14)$. Tukey test did not show any significant difference between the numbers of CFU of Hypoclean $20{ }^{\circ} \mathrm{C}$, Chlor-XTRA $20^{\circ} \mathrm{C}$ and $5 \% \mathrm{NaOCl}$ $45^{\circ} \mathrm{C}$. No differences between the $\mathrm{CFU}$ values of $\mathrm{NaOCl}$ solutions with added detergents at $20^{\circ} \mathrm{C}$ (Hypoclean and Chlor-XTRA) and $5 \% \mathrm{NaOCl}$ alone at $45{ }^{\circ} \mathrm{C}$, highlighted in this study, is no surprise. Several studies $(7,8,24)$ have reported that the addition of detergents reduced the number of bacteria within the canal after irrigation compared with $\mathrm{NaOCl}$ alone. Wettability was shown to play an important role in the penetration of disinfecting solutions into the root canal system and it depends on its surface tension (10). The addition of detergents in the used disinfecting solutions increased their antibacterial effects against $E$. faecalis in the dentinal tubules independently of the temperature, which explains the results obtained in this research. In the present study the mean numbers of CFU increased with time. The likely reason is that free available chlorine (FAC), the active component of $\mathrm{NaOCl}$-based irrigants, consumes with time (25). Presence of detergents in Chlor-XTRA and Hypoclean does not prevent consuming FAC. Significantly lower numbers of CFU obtained with Hypoclean and Chlor-XTRA compared to $\mathrm{NaOCl}$ are due probably to an increase in the depth of penetration of these solutions into dentinal tubules by decreasing surface tension and their greater wettability $(10,24)$.

In the considered experimental conditions, the results of this study suggest use of heated irrigant solutions Chlor$X$ tra and Hypoclean to improve the antibacterial activity of irrigating solutions in bovine root dentin blocks.

\section{Resumo}

0 objetivo deste estudo foi comparar a atividade antimicrobiana do hipoclorito de sódio a 5,25\%, Hypoclean e Cloro-Xtra a $20{ }^{\circ} \mathrm{C}$ e $45{ }^{\circ} \mathrm{C}$ em dentina radicular bovina. Um total de 170 tubos de dentina foram preparados a partir de incisivos superiores bovinos infectados por 21 dias com Enterococcus faecalis. Os espécimes foram divididos nos seguintes grupos: $1 . \mathrm{NaOCl}-5,25 \%$ a $20{ }^{\circ} \mathrm{C} ; 2$. Hypoclean $20{ }^{\circ} \mathrm{C} ; 3$. Cloro-Xtra 20 ${ }^{\circ} \mathrm{C} ; 4$. NaOCl- $5,25 \%$ a $45{ }^{\circ} \mathrm{C} ; 5$. Hypoclean $45^{\circ} \mathrm{C} ; 6$. Cloro-Xtra $45{ }^{\circ} \mathrm{C} ; 7$. Controle positivo; 8 . Controle negativo. Raspas de dentina foram coletadas com brocas esféricas e cultivadas em infusão cérebro coração (brain heart infusion - BHI). Após a cultura, o número de unidades formadoras de colônias (UFC) foi contado. As análises estatísticas foram realizadas utilizando estatística descritiva (média, desvio padrão, mediana), teste de Shapiro-Wilk, ANOVA e teste de Tukey. 0 nivel de significância foi estabelecido $p<0,05$. Em todos os grupos experimentais, o número de UFC foi mínimo após o tratamento inicial. Os resultados obtidos foram significativamente diferentes nos periodos de tempos experimentais $(p<0,05)$. 0 Hypoclean e o Cloro-Xtra mostraram o menor número de UFC a $20^{\circ} \mathrm{C}$ e a $45^{\circ} \mathrm{C}$, enquanto que o $\mathrm{NaOCl}-5,25 \%$ apresentou maior número de UFC em ambas as temperaturas. Em cada grupo, o número de CFUs foi significativamente aumentado por periodo de tempo $(p<0,05)$. As atividades antibacterianas do Hypoclean e Chlor-Xtra a $45^{\circ} \mathrm{C}$ foram significativamente maiores do que nas outras soluções testadas.

\section{References}

1. Rosenthal S, Spångberg L, Safavi K. Chlorhexidine substantivity in root canal dentin. Oral Surg Oral Med Oral Pathol Oral Radiol Endod 2004;98:488-492.

2. Sundqvist G. Ecology of the root canal flora. J Endod 1992;18:427-430.

3. Hess W. Anatomy of root canals in the teeth of the permanent dentition. New York: William Wood \& Co.; 1925.

4. Peters OA, Laib A, Gohring TN, Barbakow F. Changes in root canal geometry after preparation assessed by high resolution computed tomography. J Endod 2001;27:1-6.

5. Sundqvist G, Figdor D, Persson S, Sjögren U. Microbiological analysis of teeth with failed endodontic treatment and the outcome of conservative re-treatment. Oral Surg Oral Med Oral Pathol Oral Radiol Endod 1998;85,86-93.

6. Hasselgren G, Olsson B, Cvek M. Effect of calcium hydroxide and sodium hypochlorite on dissolution of necrotic porcine muscle tissue. J Endod 1998;14:125-127.

7. Palazzi F, Morra M, Mohammadi Z, Grandini S, Giardino L. Comparison of the surface tension of $5.25 \%$ sodium hypochlorite solution with 
three new sodium hypochlorite based endodontic irrigants. Int Endod J 2012;45:129-135.

8. Mohammadi Z, Giardino L, Mombeinipour A. Antibacterial substantivity of a new antibiotic-based endodontic irrigation solution. Aust Endod J 2012;38:26-30.

9. Glantz PO, Hansson L. Wetting of dentine by some root canal medicaments. Odontol Revy 1972;23:205-210.

10. Giardino L, Morra M, Becce C, Pappen FG, Mohammadi Z, Palazzi F. Comparative wettability of different sodium hypochlorite solutions. $\mathrm{G}$ It Endo 2012;26:57-62.

11. Mohammadi Z, Mombeinipour A, Giardino L, Shahriari S. Residual antibacterial activity of a new modified sodium hypochlorite based endodontic irrigation solution. Med Oral Patol Oral Cir Bucal 2011;16:e588-e592.

12. Abou-Rass M, Oglesby SW. The effects of temperature, concentration and tissue type on the solvent ability of sodium hypochlorite. J Endod 1981;7:376-377.

13. Cunningham W, Joseph SW. Effect of temperature on the bactericidal action of sodium hypochlorite endodontic irrigant. Oral Surg Oral Med Oral Pathol 1980;50:569-571.

14. Sirtes $G$, Waltimo T, Schaetzle M, Zehnder M. The effects of temperature on sodium hypochlorite short-term stability, pulp dissolution capacity, and antimicrobial efficacy. J Endod 2005;31:669-671.

15. Viswanath DS, Ghosh TK, Prasad DHL, Dutt NVK, Rani KY. Viscosity of Liquids Theory, Estimation, Experiment, and Data. 1st ed. Netherlands: Springer; 2007. p1-8.

16. Bukiet F, Soler T, Guivarch $M$, Camps J, Tassery H, Cuisinier F, et al.. Factors affecting the viscosity of sodium hypochlorite and their effect on irrigant flow. Int Endod J 2013;46:954-961

17. Gopikrishna V, Ashok P, Pradeep Kumar AR, Lakshmi LN. Influence of temperature and concentration on the dynamic viscosity of sodium hypochlorite in comparison with 17\% EDTA and 2\% chlorhexidine gluconate: An in vitro study. J Conserv Dent 2014;17:57-60

18. Myers D. Surfaces, Interfaces, and Colloids: Principles and Applications. 2nd ed. John Wiley \&t Sons, Inc. Hoboken, NJ, USA. 1999. P143.

19. Haapasalo $M, \emptyset$ rstavik D. In vitro infection and disinfection of dentinal tubules. J Dent Res 1987;66:1375-1379.

20. Mohammadi Z, Shalavi S, Giardino L, Palazzi F, Mashouf RY, Soltanian A. Antimicrobial effect of three new and two established root canal irrigation solutions. Gen Dent 2012;60:534-537.

21. Giardino L, Ambu E, Becce C, Rimondini L, Morra M. Surface tension comparison of four common root canal irrigants and two new irrigants containing antibiotic. J Endod 2006;32:1091-1093.

22. Giardino L, Estrela C, Mohammadi Z, Palazzi F. Antibacterial power of sodium hypochlorite combined with surfactants and acetic acid. Braz Dent J 2014;25:289-294.

23. Bolfoni MR, Ferla MS, Sposito OS, Giardino L, Jacinto RC, Pappen FG. Effect of a surfactant on the antimicrobial activity of sodium hypochlorite solutions. Braz Dent J 2014;25:416-419.

24. Wang Z, Shen Y, Ma J, Haapasalo M. The effect of detergents on the antibacterial activity of disinfecting solutions in dentin. J Endod 2012;38:948-953.

25. Rossi-Fedele G, Doğramaci EJ, Guastalli AR, Steier L, de Figueiredo JA. Antagonistic interactions between sodium hypochlorite, chlorhexidine, EDTA, and citric acid. J Endod 2012;38:426-431.

Received November 4, 2015 Accepted January 25, 2016 